\title{
Lessons and Challenges Encountered in the Implementation of Solar Energy - The Case of Botswana
}

\author{
C. Ketlogetswe* \\ Department of Mechanical Engineering, University of Botswana, Gaborone, P/Bag 0061, Botswana
}

\begin{abstract}
A number of photovoltaic pilot projects have been started in Botswana since 1990. The first photovoltaic project was Manyana PV project which started in 1992. The Japanese International Cooperation Agency (JICA) PV solar pilot project is the most recent PV solar project in Botswana, which was launched in 2003 at Kudumatse, Motlhabaneng, and Lorolwana villages. The primary objective of all these projects was to access the viability and sustainability of solar energy technology as an alternative source of energy especially for rural based communities. Depending on the findings, such projects were also intended to be replicated in other parts of the country. Despite all these efforts by the government of Botswana and donor agencies, the level of use of PV solar systems for power generation in Botswana, particularly in isolated communities, is very low.
\end{abstract}

This paper, therefore, discusses the factors that impede the rapid development of photovoltaics power generation systems in the rural environment of Botswana. The study is focused on the photovoltaic power generation project which was carried out in three villages in Botswana, namely Kudumatse, Lorolwana and Motlhabaneng.

Keyword: Solar energy, barriers in Botswana.

\section{INTRODUCTION}

Several governments are promoting Solar Home Systems (SHS) for the provision of energy service to stimulate sustainable development and social progress in remote communities, particularly in developing regions. Previous authors including [1] estimate that SHS provide electricity to approximately 1 million rural communities in developing countries who lack access to electricity grid. It should be noted that a huge population in developing countries, particularly in Sub-Saharan Africans live in rural settlements in small and scattered households with a relatively small electricity load requirement. Consequently, such small communities have no access to modern energy service [2]. This point is reinforced by a government report [3] which revealed that small settlements with more than 200 people lack access to an electrical grid in Botswana. It should be noted that SubSaharan Africa is not immune to the trend cited above. The lack of access to electrical energy by the majority of rural communities in Sub-Sahara is a major problem facing many governments in the region. Scattered small clusters with relatively small electrical load further make transmission and distribution of grid electrical service to be less attractive for the majority of energy providers in most parts of the developing countries, including Botswana. Based on the above observations, it is clear that the only viable option for the provision of modern energy service to isolated communities is using solar home systems.

\footnotetext{
*Address correspondence to this author at the Department of Mechanical Engineering, University of Botswana, Gaborone, P/Bag 0061, Botswana; Tel: (267) 355 4234; Fax: (267) 395 2309; E-mail: ketloget@mopipi.ub.bw
}

To respond to the lack of electricity in small settlements which are located away from the national electricity grid, the Botswana government, in collaboration with Botswana Power Corporation, the sole electricity generating and Distribution Company in the country, has launched the "Renewable Energy-Based Rural Electrification Programme" for Botswana. The programme was officially launched in October 2005. It is aimed at improving people's livelihoods by easing their access to modern energy services and its affordability. The programme sources funds through Global Environmental Funds (GEF). The primary objective is to improve people's livelihoods by improving the level of access to modern energy services in rural communities in Botswana. The activities of the project are focused on introducing different PV-based technology packages in 66 selected villages. These include solar home system, centralised PV battery charging systems, and PV mini-grid which can be powered with PV only or can be hybridised with wind generators.

The implementation processes is expected to take five years from the inception. In order to assess the impact on the introduction of PV-based rural electrification in Botswana, the authority set a number of key indicators as follows:

1) The number of PV systems sold within the first five years after the inception of the project.

2) Reduction in consumption of paraffin in households using the PV-based system.

3) The price of PV systems and the number of private dealers involved in the PV market [3]. 
Despite the financial support through Global Environmental Funds, the take-off for the programme is still considered relatively low, and concern has been expressed that the donor may pull out. This point is reinforced by observations from interviewees (mainly those at management level from Energy Affairs Division) who revealed that the donor is not happy with the slow progress of the programme [Meimah $]^{1}$.

Given the problems associated with the provision of electricity in rural areas, this paper discusses the country's experience with SHS in rural communities. The paper analyses, among other things, the factors that impede the rapid development of SHS in rural communities in Botswana despite several attempts at stimulating public interest in using solar technology for generating power. The analysis is based on the study of the recent SHS project which was carried out in three villages namely, Kudumatse, Lorolwana and Motlhabaneng from early 2002 by the Energy Affairs Division (EAD) in collaboration with the Botswana Power Corporation. The overall objective of the project was to assess feasibility of using SHS for power generation in rural communities in Botswana.

\section{LARGE - SCALE PV PROJECT IN PROGRESS IN BOTSWANA}

Preparations for the largest PV solar project in Botswana are at an advanced stage. As mentioned earlier in Section 1, project activities are focused on introducing different PVbased technology packages in 66 selected villages. The major element of the project is using SHS for the generation of energy, relying on funds sourced through GEF under its fiveyear support initiative. The Botswana Power Corporation, a government owned company and the only power generation and distribution company in the country as mentioned earlier, was sanctioned to monitor the implementation processes of the project. It is envisaged that upon confirmation of the sustenance of the project, it will make the government achieve its ambition to develop the country as a centre of excellence for solar energy technology as cited in Vision 2016, the country's blue-print for future national aspirations. However, it should be stressed that the take-off for the implementation phase is still considered relatively low as mentioned earlier. This observation is derived from the fact that the agreement for the implementation of the Renewable Energy-Based Rural Electrification Programme between the government of Botswana and the UNDP/GEF was signed in October 2005 [4].

The project aims at equipping some 65,000 households in 66 villages with solar powered photovoltaic (PV) lighting to replace the use of paraffin by 2011. It is envisaged that the approach would offer important environmental advantages including an opportunity to reduce the emission of green house gases at rural community level. However, preparations for the implementation phase as pointed out earlier are still at its infant stage. All these factors lead to the conclusion that the government's ambitions to develop the country as a centre of excellence for the solar technology by the year 2011 may not be achieved. Also the concern that the donor may withdraw support, as mentioned earlier, calls into question

\footnotetext{
${ }^{1}$ Meimah renewable energy officer.
}

the experiences, and lessons learned from previous PV solar projects cited in Sections 2.1.1 and 2.1.2.

\subsection{Experiences with PV Project in Botswana}

\subsubsection{Manyana PV Pilot Project}

A number of PV solar pilot projects have been conducted by the government of Botswana since the early 1990s, for example, the pioneer PV pilot project that the government of Botswana embarked upon is Manyana photovoltaic project in 1992. It is necessary to point out that government procedure requires that after two to three years of project inception, the project changes from pilot to a commercial status. As a result, the Manyana photovoltaic project went through the above-mentioned processes in 1995 under the auspices of the Rural Industrial Innovation Centre. The major objective of this project was to assess the viability and sustainability of solar energy technology as an alternative source of energy, specifically for rural based communities. Depending on the findings, such a project was also intended to be replicated in other parts of the country.

The project employed a sales model, in which private dealers sell solar home systems to rural households. Unlike the fee-for-service model described in Section 2.1.2, the system is owned and maintained by the household, which either pays cash in full or obtains consumer credit and is responsible for servicing the debt.

At its launch, 42 households were selected to form part of the piloting phase of the technology. Previous studies including [5] revealed that $83 \%$ of the selected households at Manyana village disconnected photovoltaic systems from their houses two years after inception. From interviews with the majority of the 42 clients, it had been alleged that lack of technical support was the main factor for disconnections. This point is given credence by observations from interviewees (mainly those at management level from Solar Industry) who revealed that the Manyana PV solar project had not proven its economic viability because there was no proper maintenance strategy put in place. Photovoltaic were installed, but end users were not properly trained in how to maintain PV solar systems, despite the sale model approach where house owners are expected to maintain their systems. Consequently, PV systems at Manyana village became nonfunctioning in less than two years after installation [Gerrit Jacobs] $]^{2}$. The observations by Jacobs are consistent with the observations by [6] who revealed that a lesson learnt from the Manyana PV pilot project is the importance of identifying a local electrician to provide supplies and service to the systems.

\subsubsection{JICA PV Pilot Project}

The most recent photovoltaic pilot project which is relevant to the present investigation is the JICA project which was carried out in three villages, namely Kudumatse, Lorolwana, and Motlhabaneng from early 2002 by the Energy Affairs Division (EAD), in collaboration with the Japanese International Cooperation Agency [JICA]. The project started in early 2002, and was completed in December 2005. Both of these pilot projects, [JICA and Manyana] aimed at

${ }^{2}$ Jacobs President of Solar International Botswana 


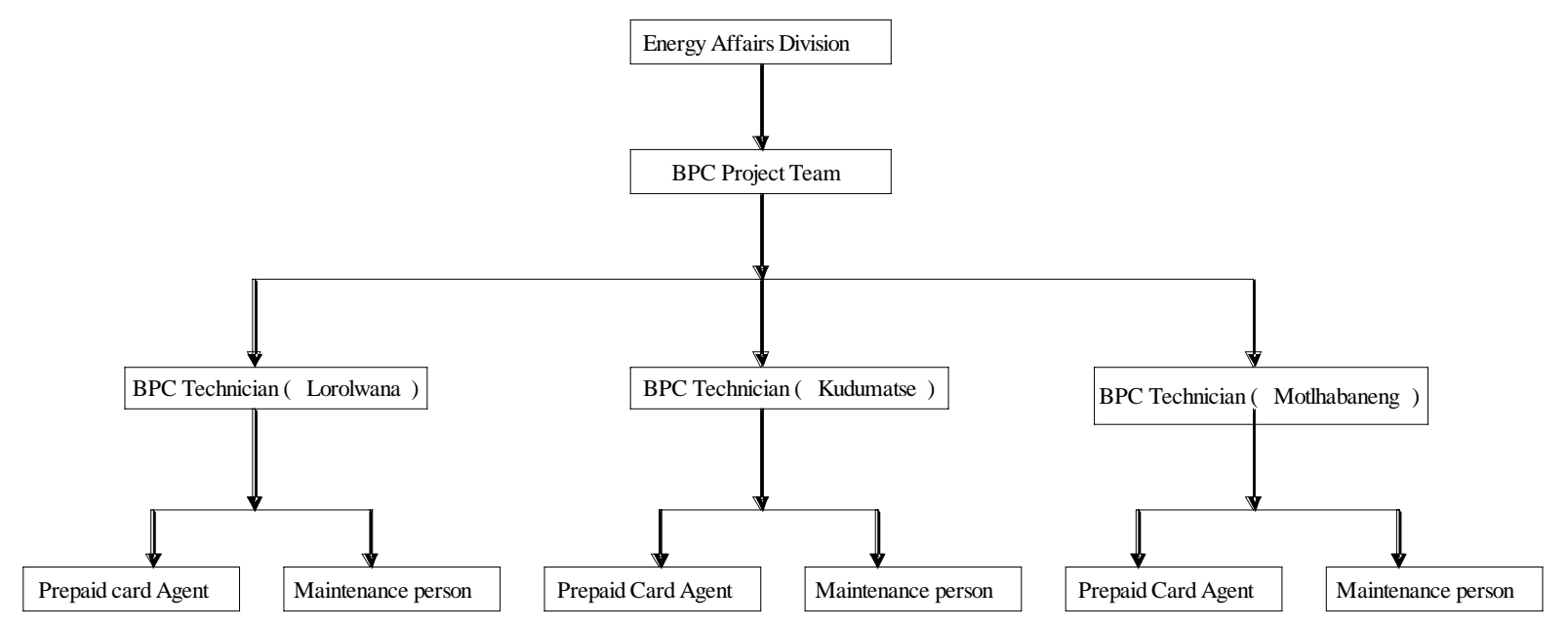

Fig. (1). Institutional framework and management system for JICA project Source: Energy Affairs Division.

providing lighting for rural dwellers using PV Solar Home System (SHS) ranging from $50 \mathrm{Wp}$ to $250 \mathrm{Wp}$, and to provide data on the technical and socio economic viability and sustainability of PV solar power generation in rural communities in Botswana. The project employed fee-for-service model. In this model an energy-service company provides electricity to households in a community for a monthly fee. However, the model is such that the system is owned and maintained by the energy service company in the specialised area.

It should be stressed that despite a strong government commitment backed by International Agencies to increase the use of renewable energy resources, the contribution of solar techniques to alleviate energy scarcity in rural communities in Botswana is minimal. A previous study by [5] revealed that the majority of PV solar projects in Botswana stop functioning after a few years of inception. This is consistent with the findings of previous studies [7] which noted that experience in Uganda showed that "payment discipline for fee-for-service model deteriorated after one year of project inception". The reason often cited is that donor projects often offer these technologies at heavily subsidised prices at the time of project inception. This suggests that the affordability level in most isolated communities in developing region is very low. This point is also echoed by [8] who argues that "the monthly fee of R50 which is equivalent to approximately US\$ 8 is not affordable to a large percentage of rural communities in the Republic of South Africa."

Although the issue of affordability appears to contribute to the low development of PV solar-based projects in rural communities in some of the SADC countries, the present study reveal that a poor institutional framework is also a major factor hampering the development of renewable technology in rural communities in Botswana. On the basis of all these factors, the current study is expected to add new information to the proposed PV-based programmes discussed in Section 2.0. The information is based on a photovoltaic power generation pilot project which was carried out in three villages as mentioned earlier in the first paragraph of Section 2.1.2.

\section{INSTITUTIONAL FRAMEWORK FOR THE JICA PROJECT}

The institutional framework for implementation of the JICA PV solar pilot project is demonstrated in Fig. (1).

The author contends that the institutional framework for the implementation of the PV projects in Botswana has a bearing on the sustainability or otherwise of renewable energy in rural communities in the country. To investigate further the sustainability and the problems that the use of PV solar home system in rural communities in Botswana is faced with, the author looked into the institutional framework for the JICA project highlighted in Fig. (1).

The role of the Energy Affairs Division is to provide policy direction on energy issues for rapid and effective development of Renewable Energy-Based Rural Electrification Programme, particularly in remote areas. The Botswana Power Corporation (BPC) is the implementing agent as mentioned earlier in Section 2.0. As a result, three teams of technical support were organised under the leadership of the BPC to provide technical service for the project in all the three villages. The team responsible for Lorolwana village was housed at the BPC main office Gaborone, while the remaining two teams were stationed at Palapye and SelebePikwe (BPC Branch Offices) to cover Kudumatse, and Motlhabaneng villages, respectively. Lorolwana is located approximately $200 \mathrm{~km}$ south of the Gaborone City, while Kudumatse and Mothabaeng are located approximately 260 and $550 \mathrm{~km}$ North of the same city, respectively. At the local village level, a maintenance officer was recruited by BPC who would report to the BPC technical officer in case of major maintenance problems which require technical assistance from the BPC. However, the present study shows that the sales of PV products were not accessible to all the three villages under review. Consequently, local maintenance persons were unable to carry out even minor maintenance work due to lack of PV spares at village level. As a result of this, participants (house owners) were expected to travel more than $100 \mathrm{~km}$ to buy small components such as PV bulbs. The situation appears to have caused ineffective energy provision to the participants in all the three villages under review. 


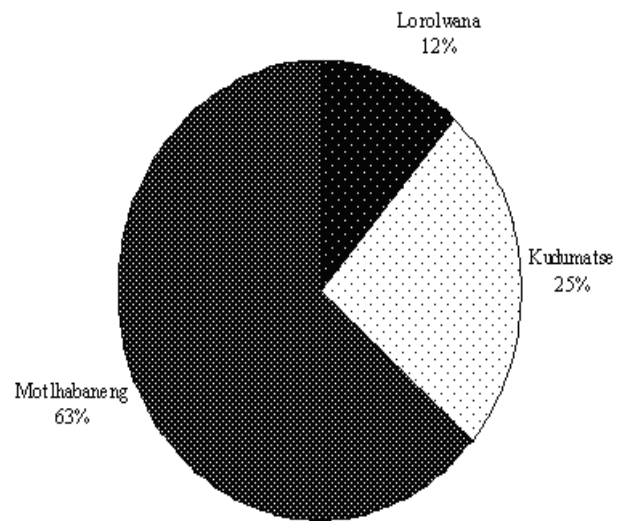

Fig. (2). Levels of technical problems recorded for JICA project.

It is the author's view that this factor is the major impediment towards promoting the rapid development of PVbased electrification in rural communities in Botswana. Based on the above observations, it can be concluded that better strategies ought to be put in place in order for sustainable development of renewable technology in the country to happen.

\section{LEVELS OF TECHNICAL PROBLEMS RECORDED}

In order to obtain more information on institutional factors which contribute to the low level of development of Renewable Energy-Based Rural Electrification Programme in the country, a data collection tool (questionnaire) was developed and used in the present study. The number of participants in Lorolwana, and Kudumatse, were 40 in each village, while in Motlhabaneng village 34 households participated in the project. It should be stressed that the success of a PV rural electrification programme depends on technical support as indicated earlier. However, the present study shows that between the inception stage and August 2005, a number of participants (house owners) in all the three villages had reported several technical problems. Fig. (2) shows the levels of technical problems recorded in all the three villages for the projects under review.
One of the trends shown in Fig. (2) is that there are significant variations in recorded technical problems. The data in Fig. (2) reveals that only $12 \%$ of the technical problems were reported for the residents of Lorolwana, as compared with $25 \%$ and $63 \%$ reported cases for Kudumatse, and Motlhabaneng respectively. Considering the number of participants in all the three villages and the location of the three villages from the BPC Main Office Gaborone, the author contends that the distance from BPC main administration office has a bearing on the number of recorded technical problems.

Overall, the results suggest that the proposed PV solar project in selected 66 villages is likely to be adversely affected by the same trend if proper maintenance strategies are not put in place. The situation is likely to lead to rejection of the use of SHS by rural communities in Botswana. Fig. (3) presents a summary of the technical problems recorded for the three rural villages, under review.

The first observation from the data in Fig. (3) is that the majority of the recorded technical problems appear to be minor problems which could easily be attended to by the local maintenance person if PV spares were made accessible at the local level. In line with the above observations, the situation seems not to be economically feasible for the BPC technical teams to make regular visits to attend to minor problems. This point is corroborated by observations from interviews with local maintenance persons at Mothabaneng village who revealed that the BPC technical team took a long time to attend to such problems.

Based on the above observations, particularly the data in Fig. (3), it is apparent that the proposed large-scale PV project would require a reliable PV solar service network system to sell PV systems, install and maintain the systems. This observation is derived from the fact that the BPC branch offices are situated in big villages. As a result, the approach of using the BPC technical staff to provide service to PV systems in 66 villages would not be cost effective for the BPC which has a mandate of providing grid electricity in the country. It should be noted that the present study reveals that the BPC encountered huge operational costs and prob-

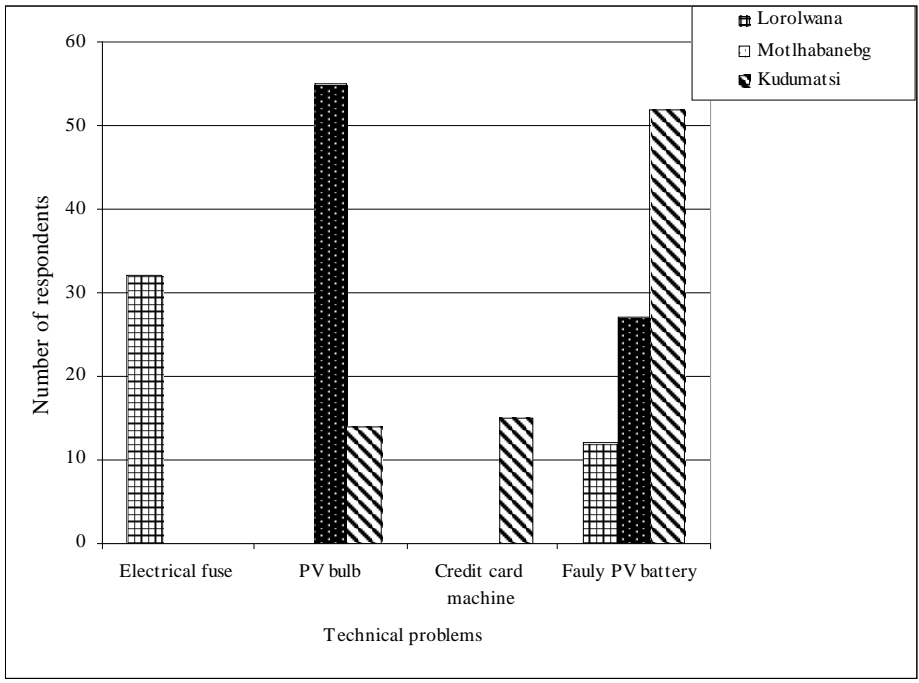

Fig. (3). Summary of technical problems for the three villages under review. 
lems with the collection of monthly fee, and service for this project. The author notes that when huge operational costs are incurred by BPC and the government, there is likely to be a corresponding increase in the need to build technical expertise at a rural level to ensure the sustainability of solar home systems in rural communities in Botswana. The author also contends that a sustainable approach is likely to reduce the perception by the public that solar technology in Botswana is of poor quality.

\section{CONCLUSION AND RECOMMENDATION}

This paper has examined the experience of Botswana in the use of renewable technology for power generation in rural communities. In particular, the study has shown that technical support provided by the Botswana Power Corporation in order to promote the rapid development and sustainability of renewable technology in rural communities in Botswana is very weak. It can be concluded that the energy authority and other major stakeholders on renewable technology do not appear to use information obtained from previous PV solar pilot projects.

The following measures are, therefore, proposed in order to stimulate a rapid development and sustainability of solar home systems in rural communities in Botswana.

1) While the use of solar home systems in rural communities in Botswana is encouraged, authorities should build technical expertise at rural community level to ensure a long term service time of solar home systems.

2) To assist sustainability of PV solar power generation in rural communities, the government should create conducive business environment for small local private companies to assist the government with the initiation of a renewable energy programme for the rural communities in Botswana.

\section{ACKNOWLEDGEMENT}

The author would like to thank Botswana Power Corporation [Re-Botswana] management for providing financial support for carrying out the research.

\section{REFERENCE}

[1] Martnon, E.; Ramankutty, R.; Rittner, F. The Global Environment Facility Solar PV Potfolio-Emerging Experience and Lessons. Monitoring and Evaluation working paper N0 2. Washington DC, 2000.

[2] Haanyika, C.M. Rural electrification policy and institutional linkages. J. Energy Policy, 2006, 34 (17), 2977-2993.

[3] Government of Botswana report BOT/00/G41/A/G/99. Identification and Overcoming Barriers to Widespread Adoption of Renewable Energy-Based Rural Electrification in Botswana. Ministry of Minerals Energy and Water Resources, 1999.

[4] Energy Affairs Division. Annual Report. Ministry of Minerals Energy and Water Resources, 2006.

[5] Ketlogetswe, C.; Mothudi, T.H. Solar home system in Botswana opportunities and constraints. J. Renewable Sustain. Energy Rev., 2009, 13, 1675-1678.

[6] Geche, J. Photovoltaic Lighting in Rural Botswana: A pilot project. Renewable Energy for Development. Stockholm Environment Institute 1996, vol. 9 (2).

[7] Nieuwenhout, F.D.; Martens, J.W.; Lansschuit, P.E.; Lafleur, M.C.C.; Cloin, J. Monitoring and Evaluation of Solar Home Systems; Experiences with Applications of Solar PV for Households in Developing Countries. ECN report (ECN-C-00-089), September 2000.

[8] Thorn. C. Criteria for the Allocation of Electrification Resources to Regions and Province. Energy and Development Centre. Republic of South Africa, 1998. 